\title{
Exaggerated and Persistent Cutaneous Delayed-type Hypersensitivity in Transgenic Mice Whose Epidermal Keratinocytes Constitutively Express B7-1 Antigen
}

\author{
Adnan Nasir, ${ }^{*}$ Barbara Ferbel, ${ }^{\star}$ William Salminen, ${ }^{\star}$ Richard K. Barth, ${ }^{\star \$ \|}$ and Anthony A. Gaspari $\$ \$ \|$ \\ ${ }^{*}$ Departments of Dermatology, ${ }^{\ddagger}$ Microbiology and Immunology, ${ }^{8}$ Strong Children's Research Center, and "Cancer Center, University of \\ Rochester School of Medicine and Dentistry, Rochester, New York 14642
}

\begin{abstract}
Since mouse keratinocytes are tolerogenic antigen presenting cells for $T$ cell activation, the expression of second signal molecules such as B7-1 was targeted to epidermal keratinocytes $(\mathrm{KC})$ in vivo in transgenic mice. The expression vector used to create transgenic mice consisted of a keratin 14 promoter fused $5^{\prime}$ to the full length open reading frame of the cDNA encoding mouse B7-1 (between 10 and 30 copies of the transgene per genome). Expression of B7-1 cell surface protein was assessed by in situ immunostaining of cryostat sections of tail skin with CTLA-4/Ig fusion protein, revealing high levels of cell surface expression of $\mathrm{B7}$ by all epidermal KC of transgenic mice, and a lack of such expression in nontransgenic animals. The skin of such transgenic mice (derived from three different founder mice) was grossly and histologically normal, with normal numbers of Langerhans cells and dendritic epidermal $T$ cells. Immunologic challenge of transgenic mice with epicutaneous haptens such as fluorescein isothiocyanate revealed enhanced and persistent delayed-type hypersensitivity responses, with an altered kinetics of resolution when compared with nontransgenic controls. These data indicate that in normal, nontransgenic mice, tolerogenic antigen presentation by $\mathrm{KC}$ plays an important physiologic role in damping $\mathbf{T}$ cell-mediated inflammation in the skin by competing with professional APC for TCR occupancy in antigen specific $\mathrm{T}$-lymphocytes that migrate into the epidermis. This also implies that altered regulation of B7-1 gene expression by epidermal cells may account for skin "hyperresponsiveness" encountered in some chronic dermatologic disorders. (J. Clin. Invest. 1994. 94:892-898.) Key words: B71 antigen - costimulation - keratinocytes • transgenic mice • peripheral tolerance
\end{abstract}

Address all correspondence to Anthony A. Gaspari, Dermatology Department, Box 697, University of Rochester School of Medicine and Dentistry, 601 Elmwood Ave., Rochester, NY 14642.

Received for publication 14 February 1994 and in revised form 11 May 1994.

1. Abbreviations used in this paper: APC, antigen-presenting cell; DETC, dendritic epidermal T cells; EC, epidermal cells; KC, keratinocytes; LC, langerhans cells.

J. Clin. Invest.

(C) The American Society for Clinical Investigation, Inc.

0021-9738/94/08/0892/07 \$2.00

Volume 94, August 1994, 892-898

\section{Introduction}

Previous in vitro studies of antigen presentation by class II MHC-bearing keratinocytes $(\mathrm{KC})^{1}$ indicated that these cells fail to activate hapten specific T-helper cells (1). Instead, antigen presentation by $\mathrm{KC}$ is tolerogenic, resulting in $\mathrm{T}$ cell clonal anergy $(2,3)$. Similarly, in an in vivo model of antigen presentation, naive mice that are first exposed to hapten modified, class II MHC-bearing $\mathrm{KC}$ are hyporesponsive to subsequent sensitization by epicutaneous application of hapten, suggesting that, in vivo, antigen presentation by $\mathrm{KC}$ is also tolerogenic, presumably inducing clonal anergy in potentially hapten reactive $\mathrm{T}$ helper cells (4).

These observations may be explained by the current two signal model for T-lymphocyte triggering. This model describes $\mathrm{T}$ cell receptor occupancy by antigen-presenting cell (APC) derived class II MHC-peptide complex as the first signal for $\mathrm{T}$ cell activation (5); the second costimulatory signal for $\mathrm{T}$ cell activation has been demonstrated to be APC derived and is neither antigen specific nor MHC restricted. A large family of APC-derived costimulatory molecules has been described (612). The B7 antigens (B7-1, B7-2, B7-3) are a group of molecules that effectively deliver this second signal, prevent the induction of clonal anergy and induce IL-2 production $(10,11$, 13-15). The $T$ cell-derived costimulatory signal receptors are CD28 and CTLA-4 (10, 11, 16, 17, 17a,b). Based on this model of antigen presentation, one may explain defective antigen presentation by $\mathrm{KC}$ to be based on their inability to provide $\mathrm{T}$ helper cells adequate costimulation because they do not express functional second signal molecules. Compatible with this hypothesis is our observation that stable expression of B7-1 by cultured human $\mathrm{KC}$ reconstitutes defective accessory cell and alloantigen presenting functions (18), two in vitro functions usually associated with professional APC such as dendritic cells, activated macrophages, or B-lymphocytes. Because $\mathrm{KC}$ are naturally occurring tolerogenic APC, we hypothesize that epidermal KC may play an important role in maintaining peripheral tolerance by counterbalancing the potent $\mathrm{T}$-helper cell immunostimulatory capacities of epidermal Langerhans cells (LC) (19). To test this hypothesis, we developed a line of transgenic mice whose epidermal KC express, in situ, high levels of cell surface B7-1 antigen. In this report, we describe these mice: they have exaggerated and persistent cutaneous delayed type hypersensitivity reactions.

\section{Methods}

Mice. $(\mathrm{DBA} / 2 \mathrm{~J} \times \mathrm{C} 57 \mathrm{BL} / 6) \mathrm{F} 1$ mice were obtained from The Jackson Laboratories (Bar Harbor, ME) and housed in a specific pathogen-free animal barrier facility at the University of Rochester. 


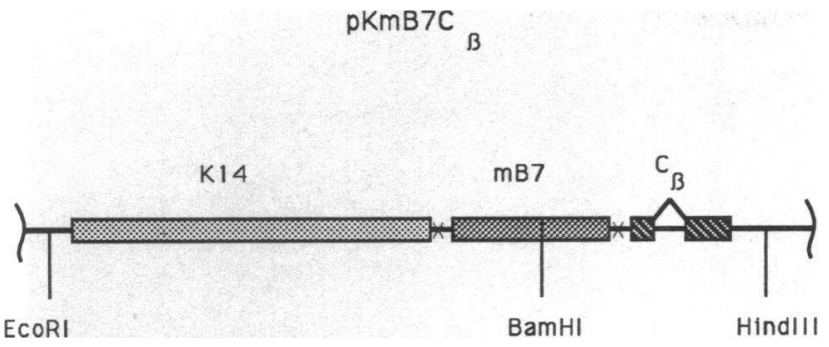

Figure 1. Expression vector construct. $\mathrm{K} 14-\mathrm{mB}^{-} \mathrm{C}_{\beta}$ construct was linearized by digestion of $\mathrm{pKmB7C} \mathrm{C}_{\beta}$ with EcoRI and HindIII. The linearized DNA was further digested with ScaI and separated from pGEM3Z vector (flanking K14-mB7- $\mathrm{C}_{\beta}$, not shown) by centrifugation over a 10 $40 \%$ sucrose gradient. The resultant DNA was dialyzed and microinjected into the pronuclei of fertilized mouse eggs, which were transferred to pseudo-pregnant females as described in Methods to create B7-1 transgenic mice.

Reverse transcription-polymerase chain reaction. RNA purification, cDNA, and PCR amplification were carried out as described with slight modifications (20). RNA was isolated from cells in guanidinium isothiocyanate lysing buffer with subsequent $\mathrm{CsCl}$ step gradient purification as described. RNA was extracted from mouse $\mathrm{C} 3 \mathrm{H} / \mathrm{HeJ}$ spleen cells, and quantitated using spectrophotometry; cDNA was then prepared by reverse transcription with Moloney murine leukemia virus reverse transcriptase (GIBCO/ BRL, Gaithersburg, MD). The PCR was performed using Taq polymerase (Boehringer Mannheim, Indianapolis, $I N$ ) and a $5^{\prime}$ oligonucleotide primer of B7 (corresponding to nucleotides 229-260 of published cDNA sequence) (21) paired with a $3^{\prime}$ oligonucleotide primer of B7 (corresponding to nucleotides 1236-1207 of the published cDNA sequence) (21); these oligonucleotides fully encompass the open reading frame (nucleotides 249-1166). Denaturation, annealing, and extension reactions were carried out at $94^{\circ} \mathrm{C}$ for $15 \mathrm{~s}, 56^{\circ} \mathrm{C}$ for $15 \mathrm{~s}$, and $72^{\circ} \mathrm{C}$ for $30 \mathrm{~s}$, respectively, for 30 cycles. Three isoforms of the B7 RNA molecule were identified: $1.0,0.9$, and $0.6 \mathrm{~kb}$ (data not shown). The identity of the longest product was confirmed by restriction mapping and sequencing to be that of the published B7 cDNA containing the entire open reading frame. This was cloned directly into the pCRII TA cloning vector (Invitrogen, San Diego, CA).

Expression vector construct. To target the expression of B7 to epidermal KC, we used a K14 promoter (gift of Dr. Elaine Fuchs, University of Chicago), which has previously been used to target transgenes to epidermal KC (22). The K14 cassette, which is incorporated into pGEM3Z vector (Promega, Madison, WI), was modified to incorporate splice donor and acceptor sites. The K14 poly A region was excised by digesting with BamHI and Hind III. The third and fourth exons of the $\mathrm{C}_{\beta}$ gene (23), which include a 3' untranslated region and polyadenylation signals, were incorporated into the $\dot{\mathrm{K}} 14$ poly A deficient cassette at the BamHI/ Hind III sites. The $1.0 \mathrm{~kb}$ mouse B7 cDNA was then cloned into the BamHI site of the hybrid vector to yield $\mathrm{pKmB7C}_{\beta}$ (See Fig. 1). Using DNA mediated gene transfection, we have previously demonstrated that this expression construct is sufficient to induce cell surface expression of functional mouse B7-1 by cultured mouse and human KC (24).

Transgenic mice. $\mathrm{pKmB7C_{ \beta }}$ DNA was digested with EcoRI/HindIII to liberate $\mathrm{K} 14-\mathrm{mB} 7-\mathrm{C}_{\beta}(3.6 \mathrm{~kb})$ from pGEM3Z, and further digested with ScaI, which digests a single site in pGEM3Z $(2.7 \mathrm{~kb})$ to create two smaller fragments $(1.8,0.9 \mathrm{~kb})$. The insert DNA was separated from the two fragments by $10-40 \%$ sucrose density gradient centrifugation as described (25), dialyzed extensively in $\mathrm{H}_{2} \mathrm{O}$, quantitated, and resuspended in $1 \times$ injection buffer at a concentration of 10 micrograms $/ \mathrm{ml}$. The DNA was then microinjected into $(\mathrm{DBA} / 2 \mathrm{~J} \times \mathrm{C} 57 \mathrm{BL} / 6) \mathrm{F} 1$ fertilized eggs which were then implanted in pseudopregnant females using standard techniques (26).

Southern blot. Genomic DNA was extracted from tail skin, electrophoresed on $2.5 \%$ agarose gel, transferred to nitrocellulose and probed for the expression of the transgene with ${ }^{32} \mathrm{P}$-labeled linearized $\mathrm{K} 14$ $\mathrm{mB} 7-\mathrm{C}_{\beta}$, using standard methodology (27).

In vitro costimulation assay. Purified T-lymphocytes were prepared from spleen cells (nontransgenic F1 mice) as previously described, using a nylon wool column followed by antibody and complement (28). $10 \mathrm{~d}$ passaged mouse KC (derived from transgenic or nontransgenic mice), devoid of LC, were plated into microtiter plates and allowed to adhere for $1 \mathrm{wk}$. Immediately before the assay, the $\mathrm{KC}$ were irradiated with $2,000 \mathrm{rad}(1 \mathrm{rad}=0.01 \mathrm{~Gy})$ to prevent cell proliferation. These $\mathrm{KC}$ were assayed for their ability to costimulate Concanavalin A (Sigma Chemical Co., St. Louis, MO) (10 $\mu \mathrm{g} / \mathrm{ml}$ final concentration) induced $\mathrm{T}$ cell proliferation in $\mathrm{T}$ cell medium (1). $10^{5}$ purified $\mathrm{T}$ cells were incubated with the adherent $\mathrm{KC}$ in the presence or absence of Concanavalin $\mathrm{A}$. The 96-well plates were incubated at $37^{\circ} \mathrm{C}, 5 \% \mathrm{CO}_{2}$ for $72 \mathrm{~h}$, and pulsed with $1 \mu \mathrm{Ci}$ of $\left[{ }^{3} \mathrm{H}\right] \mathrm{TdR}$ per well $(1 \mathrm{Ci}=37 \mathrm{GBq}$ ) (Dupont NEN, Boston, MA) during the last $18 \mathrm{~h}$ of culture, harvested, and counted using scintillation counting. Counts are represented as mean cpm of triplicate wells. SEM were $<10 \%$.

Antibodies and flow cytometry. Primary epidermal cell (EC) suspensions were made as previously described (29), except that mouse skins were incubated with a 1:10 dilution of the enzyme dispase (Collaborative Research, Boston, MA) (for $30 \mathrm{~min}$ at $37^{\circ} \mathrm{C}$ ), which was substituted for $0.5 \%$ trypsin. $10^{6}$ cells were incubated in $10 \%$ normal goat serum for $10 \mathrm{~min}$ at room temperature to saturate any potential $\mathrm{Fc}$ receptor binding. The cells were then washed in FACS wash buffer $(0.1 \%$ bovine serum albumin $/ 0.01 \%$ sodium azide) and then incubated with uncoupled primary antibodies for $20-60 \mathrm{~min}$ at $4^{\circ} \mathrm{C}$. The primary antibodies were as follows: CTLA-4/Ig (a gift from Dr. Peter Linsley, Bristol-Myers Squibb, Seattle, WA), control Ig, M5/1 14 (anti-class II MHC, hybridoma cells from ATCC, Rockville, MD), 30-H12 (anti-Thy 1.2, hybridoma cells from ATCC), 53-67.2 (anti-CD8, hybridoma from ATCC) and GK-1.5 (anti-CD4, hybridoma cells from ATCC). Staining was detected using second step reagents: fluorescein conjugated $\mathrm{F}(\mathrm{ab})_{2}{ }^{\prime}$ fragments of goat anti-human IgG (1:320 dilution) (to detect staining with CTLA-4/ Ig or control Ig) (Cappel, Organon Teknika, Durham, NC) or fluorescein conjugated $\mathrm{F}(\mathrm{ab})_{2}{ }^{\prime}$ fragments of goal anti-rat IgG (1:40 dilution) (Cappel). One color flow cytometric analysis was performed on an EPICS flow cytometer (Coulter Immunology, Hialeah, FL). Logarithmically amplified fluorescence data were collected on $10^{4}$ viable cells as determined by forward light scatter intensity. These data were analyzed using the software program Cytologos (Coulter Immunology, Hialeah, FL).

Immunohistochemistry. Biopsy specimens were obtained from distal tail, embedded in OCT medium (Miles Laboratories, Elkhart, IN), snap frozen, and 5- $\mu \mathrm{m}$-thick cryostat sections were cut onto glass slides. They

Figure 2. Identification of a B7-1 transgenic founder mouse. Genomic DNA was extracted from tail skin from 3 different animals, digested with BamHI, electrophoresed, transferred to nitrocellulose, and probed for the expression of the $\mathbf{B} 7$ transgene using ${ }^{32} \mathrm{P}$ labeled, linearized $\mathrm{K} 14$ $\mathrm{mB}-\mathrm{C}_{\boldsymbol{\beta}}$ construct. Copy control number indicates that transgenic founder (number 26) has between 10-30 copies of the transgene per genome. Using the above described methods, two other transgenic mouse lines were also identified (data not shown). 

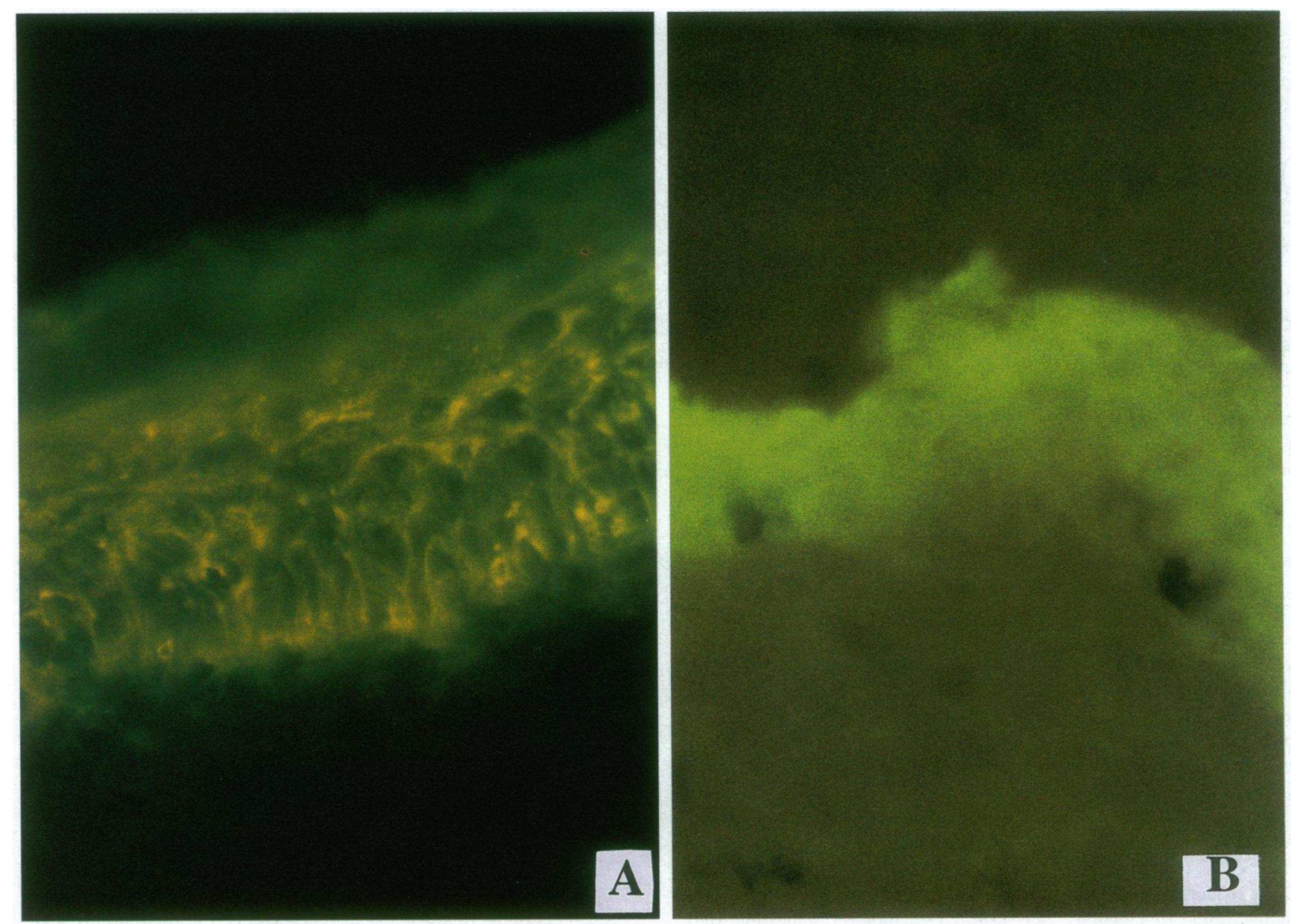

Figure 3. In situ expression of B7-1 in the skin of transgenic and nontransgenic mice. Cryostat sections of tail skin (Line 26) were stained for B71 expression by indirect immunofluorescence as described in Methods. $(A)$ Transgenic mouse, with bright staining with CTLA-4/Ig, indicating a high level of cell surface expression of B7-1 on virtually all epidermal KC. Similar staining patterns were noted in two other transgenic mouse founders (data not shown). $(B)$ Non-transgenic mouse, with no detectable B7 expression observed $(\times 25)$.

were fixed for $5 \mathrm{~min}$ at $4^{\circ} \mathrm{C}$ in acetone, and then washed. The specimens were then stained with uncoupled $10 \mu \mathrm{g} / \mathrm{mL}$ CTLA-4/Ig or control Ig. Staining was detected using fluorescein coupled $\mathrm{F}(\mathrm{ab})_{2}{ }^{\prime}$ fragments of goat anti-human Ig. The specimens were examined using a Jena Lumar epifluorescence microscope (Zeiss, Federal Republic of Germany); photomicrographs were also obtained using the same microscope.

Contact hypersensitivity assay. Contact sensitization to FITC was assayed as previously described (30). Ear swelling was measured using thickness gauge calipers (Swiss Precision Instruments, Carlstadt, NJ) at the time points indicated after challenge on the pinna of the ear. Treatment groups included sensitized and naive mice ( $n=4$ in each group), with both transgenic and nontransgenic mice being studied. Data is reported as the mean change in ear thickness, $\Delta \mathrm{T}=[$ (Thickness after challenge) - (Baseline Thickness)], plus/minus the standard error of the mean.

For the in vivo blocking study of the ear swelling response in transgenic mice, groups (four animals in each group) of naive transgenic mice were challenged on the pinna of the ear with a single epicutaneous application of $20 \mu \mathrm{l}$ of $0.5 \%$ FITC. Before this challenge, one group of animals was treated with a single intradermal injection of CTLA-4/Ig $20 \mu \mathrm{g}$ in a $20 \mu \mathrm{l}$ volume (blockade group); another group of transgenic mice received $20 \mu \mathrm{l}$ of phosphate buffered saline (control group). A third group of mice (nontransgenics) served as a negative control for the ear swelling response in naive mice, and received a single epicutaneous application of $0.5 \%$ FITC without any prior injections. Ear swelling was then measured at the indicated time intervals.

Statistical analysis. The ear swelling data were analyzed for statisti- cal significance using the one tailed, paired student's $t$ test (software program Statview SE + graphics, Abacus Concepts, Berkeley, CA.) $P$ values $<0.05$ were considered significant.

\section{Results}

Transgenic mice were identified using Southern blotting of genomic DNA (BamHI digest) extracted from tail skin. As depicted in Fig. 2, genomic DNA from three different mice indicated that mouse number 26 was transgenic, and the corresponding littermates (numbers 29, 14) were nontransgenic. Comparison of the intensity of the band resulting from the presence of the transgene to that of the copy number control indicated that there were between 10-30 tandem copies of the transgene per genome in mouse number 26 , the founder of the transgenic mouse line that we established. We also identified two other transgenic founder mice by southern blotting (data not shown). To confirm that our founder mice indeed expressed B7-1 cell surface protein, we studied frozen sections of mouse skin by immunofluorescence microscopy for CTLA-4/Ig binding. As indicated in Fig. $3 A$, there was bright cell surface staining of all layers of epidermal $\mathrm{KC}$ by CTLA-4/Ig in all transgenic mouse lines, indicating strong B7 expression. This pattern was 
B7 EXPRESSION BY TRANSGENIC AND WILD TYPE EC

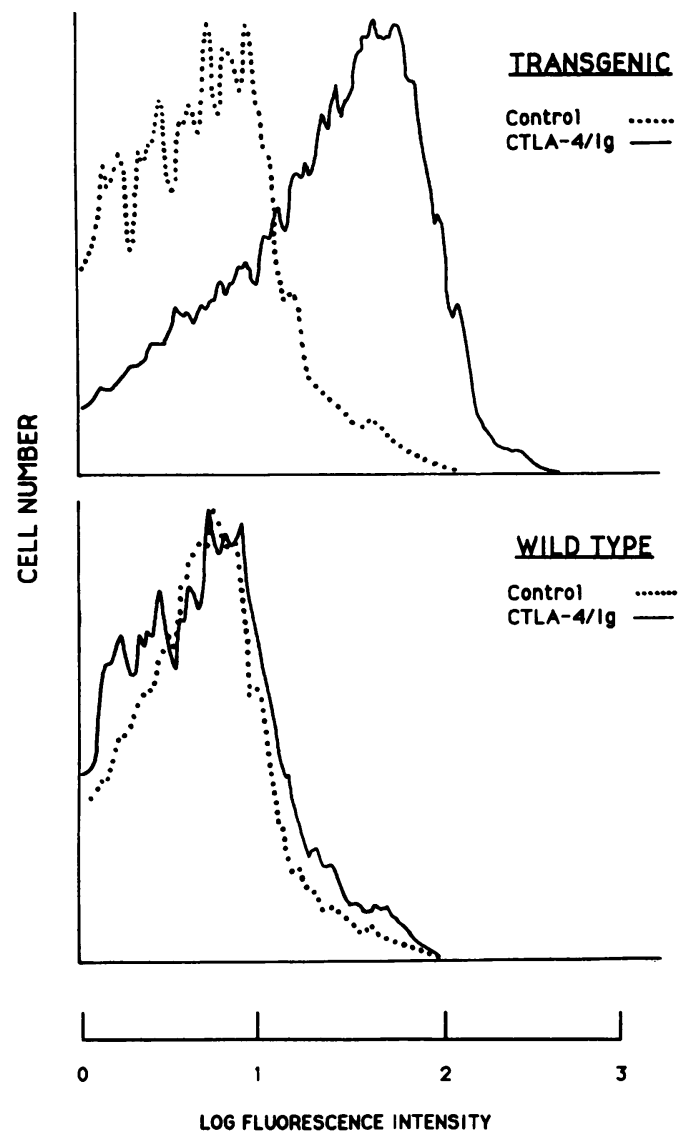

Figure 4. Flow cytometry of EC suspensions from transgenic and nontransgenic mice. Single cell suspensions of EC were prepared from transgenic (top panel) and nontransgenic mice (bottom panel) and stained for B7 expression as described in Methods. As depicted, the majority of EC from transgenic mice were $\mathrm{B}^{+}$, whereas all EC from nontransgenic mice were $\mathrm{B}^{-}$, similar to the pattern of staining noted in cryostat skin sections.

highly reproducible in skin sections taken from tail as well as other sites (ear, trunk) in this mouse and remained stable in subsequent transgenic offspring. This pattern of staining was not observed with control Ig in either transgenic or nontransgenic mice (data not shown). There was no CTLA-4/Ig binding in tail sections taken from nontransgenic mice (Fig. 3 $B$ ). To further confirm the cell surface expression of B7-1 by mouse $\mathrm{KC}$, we studied single cell suspensions of epidermal cells from transgenic mice and compared them with nontransgenic littermates. Our initial studies of epidermal cells from transgenic mice suggested that B7-1 antigen expression was sensitive to proteolytic cleavage by $0.5 \%$ trypsin used to prepare single cell suspensions of epidermal cells, thus ablating CTLA-4/Ig binding activity (data not shown). Therefore, we used another enzyme, dispase, to prepare single cell suspensions of epidermal cells for flow cytometry (see methods). As indicated in Fig. 4, there was a significant level of CTLA-4/Ig binding in epidermal cells from transgenic mice, but a lack of such reactivity in epidermal cells from nontransgenic mice. We also studied epidermal cell suspensions for the presence of epidermotropic bone marrow derived cells. There was no difference in the frequency of $\mathrm{Ia}^{+}$cells (LC) or Thy $1^{+}$cells (DETC) in the epidermis of
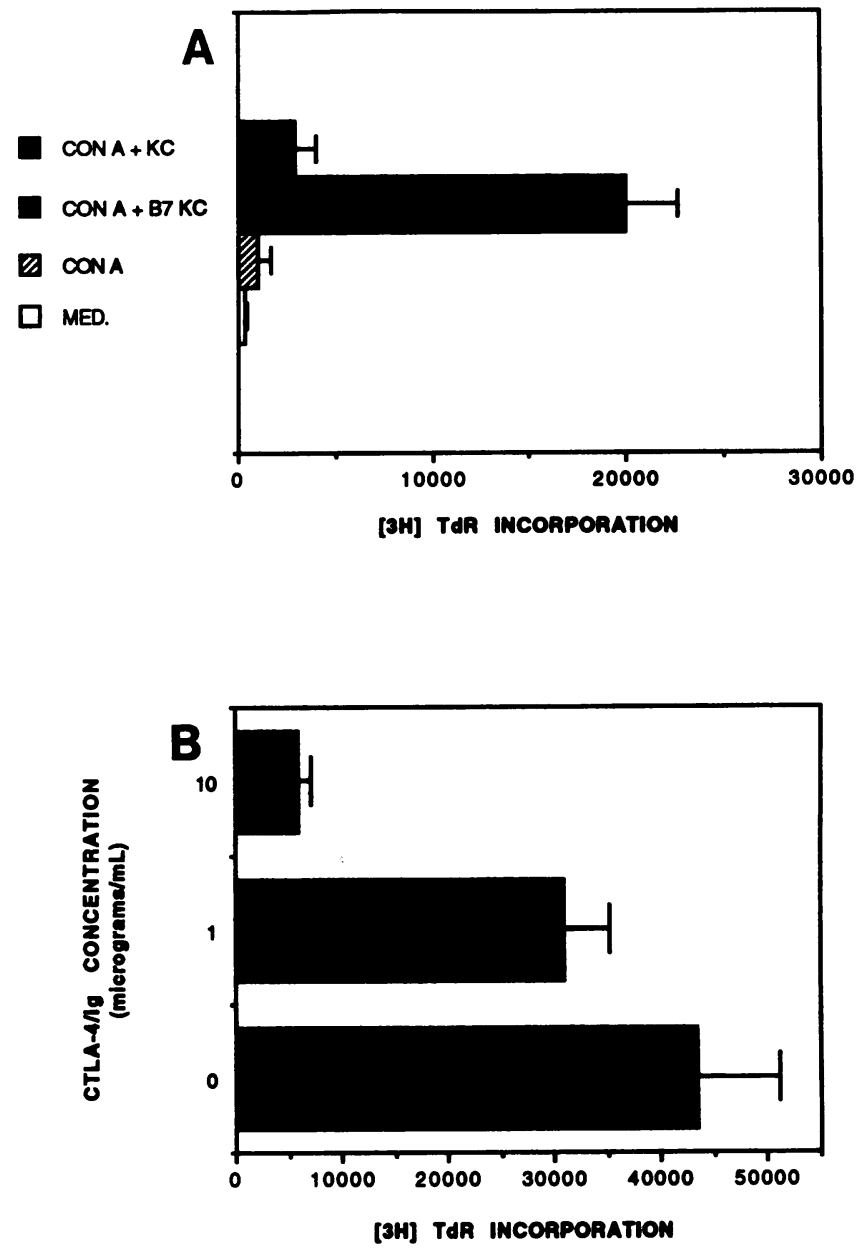

Figure 5. In vitro costimulation of $\mathrm{T}$ cell proliferative responses by $\mathrm{KC}$ from B7 transgenic mice and blocking with anti-B7 reagents. Highly purified T-cells $\left(10^{5} /\right.$ well) from normal $F 1$ mice were co-cultured with 7,500 plastic adherent KC. Only those T cells co-cultured with KC from transgenic mice proliferated significantly in response to Concanavalin A (10 $\mu \mathrm{g} / \mathrm{ml}$ ). $\mathrm{T}$ cells co-cultured with $\mathrm{KC}$ alone did not proliferate (data not shown) (A). CTLA-4/Ig (1.0 or $10 \mu \mathrm{g} / \mathrm{ml}$ final concentration), when added to the co-cultures of transgenic KC $(6,000 /$ well) and purified T cells, blocked the costimulation of concanavalin $\mathrm{A}$ induced $\mathrm{T}$ cell proliferation; Control Ig did not block the proliferation (data not shown) $(B)$.

transgenic mice when compared with nontransgenic littermates (data not shown). This indicates a normal frequency of LC and $\gamma / \delta$ bearing DETC in transgenic mice compatible what has been reported for other strains of normal mice (31). Similarly, all three transgenic mouse lines (heterozygotes) were normal in their activities, growth and development. The histology of their skin was normal (data not shown).

To demonstrate that $\mathrm{KC}$ from transgenic mice expressed functional B7-1, we studied the ability of such $\mathrm{KC}$ to costimulate $\mathrm{T}$ cell proliferation $(100,000 /$ well $)$ in response to polyclonal $\mathrm{T}$ cell activators such as Concanavalin A $(10 \mu \mathrm{g} / \mathrm{ml})$. As depicted in Fig. $5 \mathrm{~A}$, cultured $\mathrm{KC}$ (7,500/well) from transgenic mice costimulated significant mitogen induced $\mathrm{T}$ cell proliferation, whereas equal numbers of $\mathrm{KC}$ from nontransgenic controls failed to induce any response. The costimulation provided by such transgenic KC was dependent on B7-1 expression, as CTLA-4/Ig blocked, in a dose dependent fashion (1 or $10 \mu \mathrm{g} /$ $\mathrm{mL})$, the ability of transgenic $\mathrm{KC}(6,000 /$ well $)$ to support $\mathrm{T}$ cell 

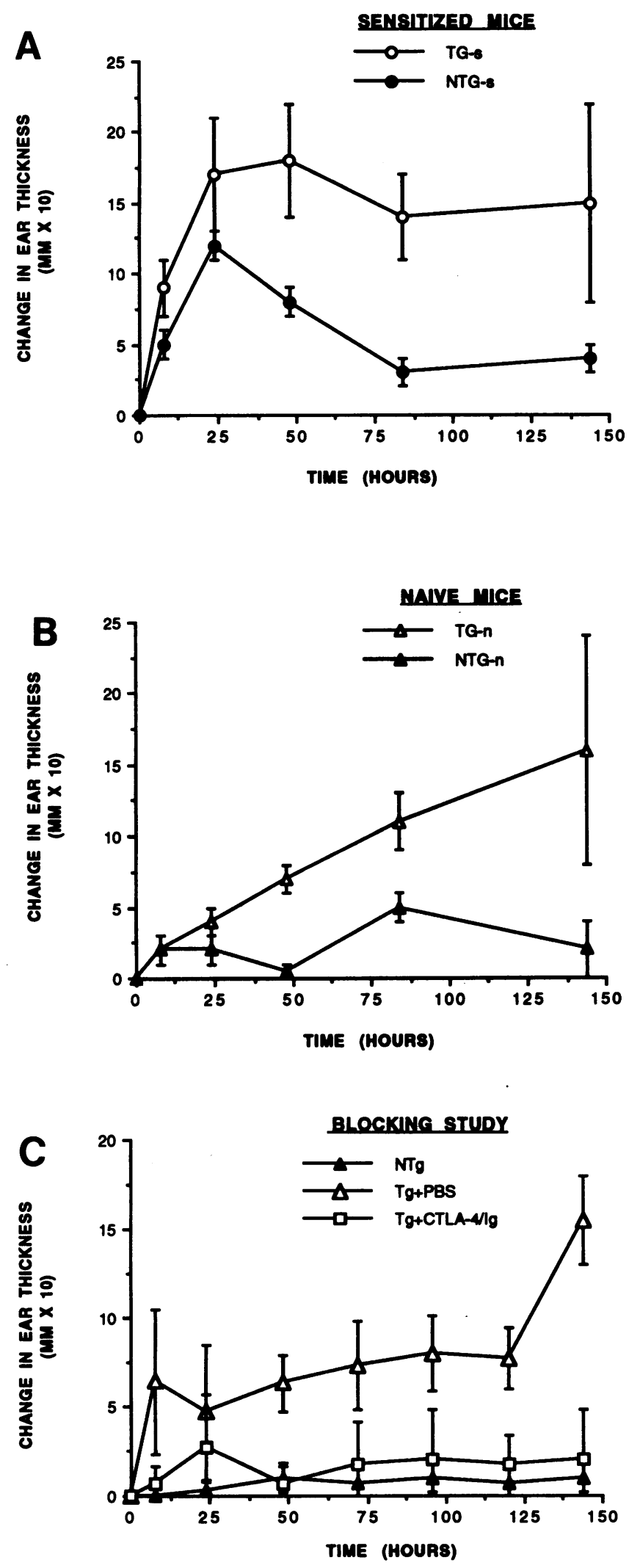

Figure 6. Time course of the ear swelling response to epicutaneous hapten application in sensitized and naive mice and blocking with antiB7 reagents. Transgenic or nontransgenic animals were challenged on the pinna of the ear $6 \mathrm{~d}$ after painting abdominal skin with $0.5 \%$ FITC (sensitized) $(A)$ or without previous painting (naive) $(B)$. In both the sensitized and naive groups, the transgenic mice developed a persistent ear swelling response. To block the progressive ear swelling response, proliferation (Fig. $5 \mathrm{~B}$ ). Control Ig did not block the transgenic $\mathrm{KC}$ costimulation response (data not shown).

Using the sensitizer $0.5 \%$ FITC (30), we studied contact hypersensitivity in transgenic mice (two different transgenic mouse lines) and nontransgenic littermates. At $24 \mathrm{~h}$, the peak of the typical ear swelling response, there was no significant difference when comparing transgenic to nontransgenic littermates (See Fig. 6, $A$ and $B$ ). However, at later time points in the transgenic mice, but not the nontransgenic mice, there was a continued crescendo in the ear swelling that persisted for $144 \mathrm{~h}$. This difference between transgenic and nontransgenic mice at the 84-h time point was statistically significant ( $P$ $<0.05)$. This same pattern of exaggerated and persistent ear swelling was noted in a second line of B7-1 transgenic mice (24 h ear swelling of sensitized mice: Transgenic $\Delta \mathrm{T}=16 \pm 3$; non-transgenic $\Delta \mathrm{T}=11 \pm 2 ; 144 \mathrm{~h}$ ear swelling of sensitized mice: Transgenic $\Delta \mathrm{T}=14 \pm 4$; nontransgenic $\Delta \mathrm{T}=2 \pm 1$ ).

Interestingly, there was also a difference in the kinetics of the ear swelling response of naive control animals, with the transgenic mice again demonstrating a crescendo in ear swelling up to $144 \mathrm{~h}$. The progressive in vivo ear swelling response in transgenic mice was dependent on B7-1 expression, as a single subcutaneous injection of $20 \mu \mathrm{g}$ of CTLA-4/Ig before the epicutaneous application of hapten prevented this phenomenon in CTLA-4/Ig treated, but not sham treated mice (See Fig. $6 C$ ).

We studied the histology of the sustained ear swelling response in transgenic and nontransgenic naive controls in our contact hypersensitivity assay. Biopsy specimens taken from the pinna of the ear of transgenic mice $21 \mathrm{~d}$ after the application of FITC were dramatically different than specimens taken from nontransgenic controls. In specimens from transgenic mice, there was epithelial hyperplasia, vasodilation of dermal capillaries as well as an inflammatory cell infiltrate comprised of mononuclear cells, neutrophils and melanophages (Fig. 7 A). All of these changes were absent in biopsy specimens taken from nontransgenic controls, in which the inflammation had resolved completely, resulting in histologically normal skin (Fig. 7 B).

\section{Discussion}

There is great interest in understanding the outcome of interactions between T-helper cells and APC. Numerous studies have demonstrated that the characteristics of the APC determine the outcome of this interaction: $T$ cell activation or tolerance induction (clonal anergy) (5). Whereas professional APC express abundant class II MHC as well as costimulatory molecules, nonlymphoid cells such as KC may be induced to express class II MHC but do not express critical costimulatory molecules (1-3). Numerous in vitro models of antigen presentation have confirmed the importance of multiple APC-derived second signal molecules (B7-1, B7-2, B7-3 and possibly other members of the immunoglobulin supergene family) (615). Likewise, there are at least two T-cell receptors for this costimulatory activity (CD28, CTLA-4 and possibly other heretofore uncharacterized molecules) $(17 \mathrm{a}, \mathrm{b})$. The redundancy of this system

we treated a group of transgenic mice with a single subcutaneous injection of CTLA-4/Ig (20 $\mu \mathrm{g}$ in a $20 \mu \mathrm{l}$ volume); another group of transgenic mice received $20 \mu \mathrm{L}$ of PBS before being challenged with an epicutaneous application of $20 \mu \mathrm{l}$ of $0.5 \%$ FITC; a group of nontransgenic mice served as a negative control, and received only a $0.5 \%$ FITC challenge $(C)$. 

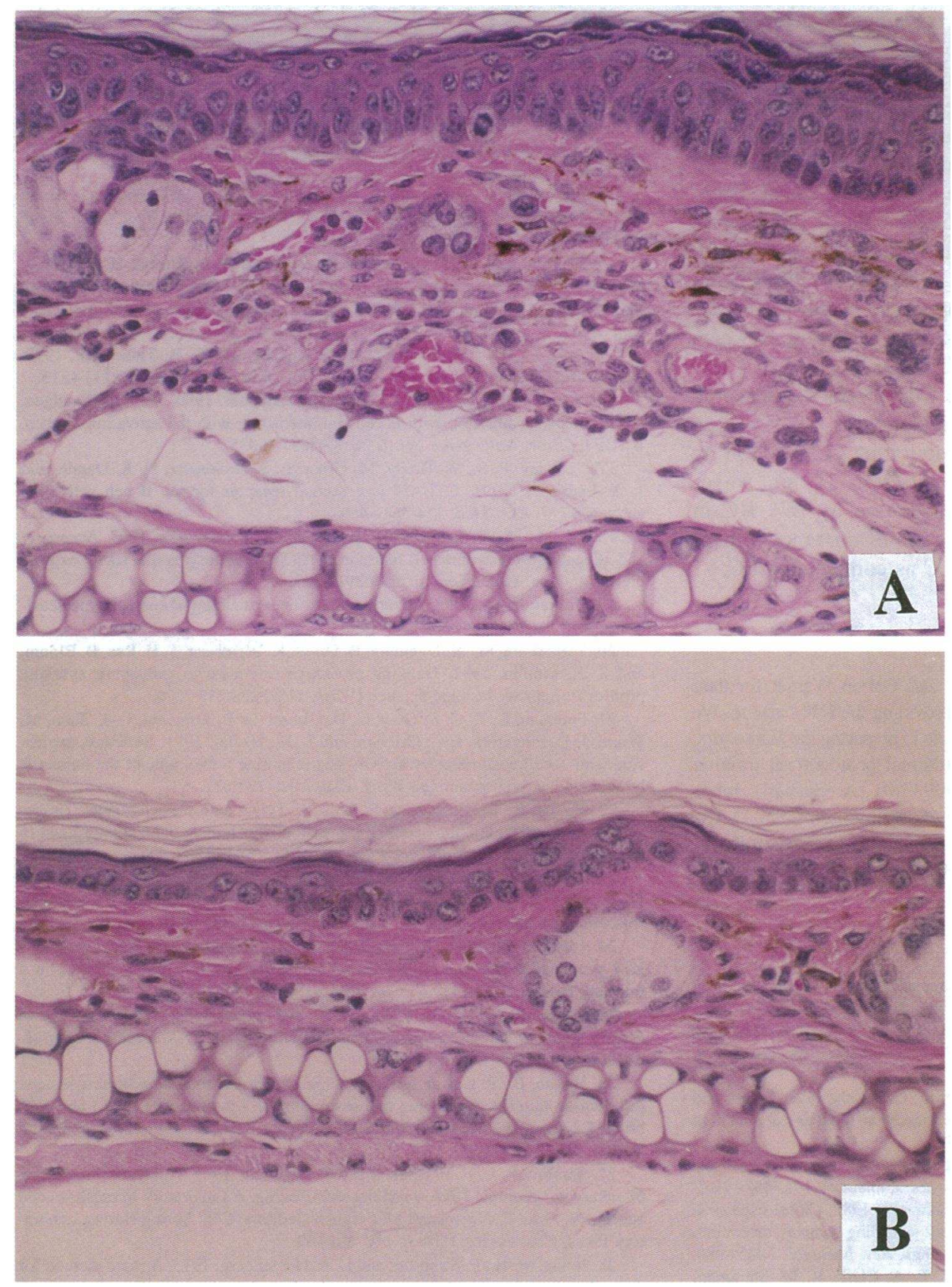

Figure 7. Histologic study of the persistent delayed type hypersensitivity reaction in the skin of transgenic mice. $21 \mathrm{~d}$ after the application of $0.5 \%$ FITC to the pinna of the ear of naive control transgenic or nontransgenic mice, biopsy specimens were taken for histologic examination. $(A)$ Ear skin from a transgenic mouse, with persistent inflammation. (B) Ear skin from a non-transgenic mouse, in which the inflammatory response has completely subsided (Hematoxylin and Eosin, $\times 40$ ). indicates its importance in immune function, but also renders the interpretation of in vivo studies difficult. For example, disruption of the B7-CD28 activation pathway in transgenic CD28-knockout mice resulted in a partial immunodeficiency state (32), suggesting that CD28 is not required for all $\mathbf{T}$ cell responses in vivo and that alternative costimulatory pathways exist and may be important.

Our transgenic mice are the first example of the aberrant expression of this costimulatory ligand by naturally occurring tolerogenic APC (i.e., KC). Since stable expression of B7-1 antigen in vitro by DNA mediated gene transfection renders $\mathrm{KC}$ as well as other $\mathrm{B}^{-}$cell lines to become competent $\mathrm{APC}(18,33,34)$, we reasoned that targeting $\mathrm{B} 7-1$ to the epidermal $\mathrm{KC}$ of transgenic mice would induce such $\mathrm{KC}$ to become competent APC. The absence of tolerogenic APC may result in a loss of peripheral tolerance, and possibly skin disease. We have not observed any spontaneous dermatologic abnormalities in these heterozygous mice (observations of three different transgenic mouse lines up to 9 mo of age, data not shown). However, our studies of cutaneous delayed type hypersensitivity indicate that B7-1 transgenic mice differ in their responses to allergens, despite a normal skin architecture and normal numbers of LC and DETC. The nature of contact hypersensitivity differs qualitatively and quantitatively when compared to nontransgenic mice in that the amplitude and kinetics of later phases of the contact hypersensitivity reaction are significantly dissimilar. It is interesting that the most profound alterations in contact hypersensitivity were observed in the resolution phase of the inflammatory response. It is known that during contact hypersensitivity reactions, class II MHC antigen expression is induced on the cell surface of $\mathrm{KC}$, presumably because of interferon$\gamma$ released by activated $\mathrm{T}$-lymphocytes that have migrated to the skin (35).

Based on our previous studies of $\mathrm{Ia}^{+} \mathrm{KC}$, we hypothesized 
that KC play an important role in the resolution of delayed type hypersensitivity reactions in the skin based on their ability to induce T-helper cell clonal anergy. That is, antigen presentation by $\mathrm{Ia}^{+} \mathrm{KC}$ acts to downregulate responsiveness and to resolve cutaneous delayed type hypersensitivity. Our comparative studies of contact hypersensitivity in transgenic and non-transgenic mice are compatible with our hypothesis that the $\mathrm{KC}$-induced clonal anergy mechanism plays an important physiologic role in situ by preventing exaggerated DTH reactions in the skin by competing with professional APC for TCR occupancy in antigen specific, epidermotropic T cells. Such anergic T-lymphocytes would be unable to elaborate lymphokines such as $\mathbb{I}-2$ and interferon- $\gamma$, which would then amplify a cutaneous DTH reaction.

It will be interesting to determine whether these transgenic mice will be resistant to tolerance induction to delayed type hypersensitivity mediated by the disruption of LC function by irradiating the skin with ultraviolet light (290-320 nm wavelength). In this scenario, antigen presentation by $\mathrm{B} 7^{+} \mathrm{KC}$ in transgenic mice may prevent the induction of tolerance to haptens because KC may substitute for LC as competent APC.

\section{Acknowledgments}

We thank Drs. David Scott, John Frelinger and Garvin Warner for their useful discussions, and Dr. Elaine Fuchs for providing the K14 cassette. We acknowledge Ms. Margaret Piscitello for her role in preparing the manuscript.

This research was supported by Institutional postdoctoral training grant 532 AR07472 (A. Nasir), 1R29AR40933-01 (A. Gaspari), Johns Hopkins Center for Alternatives to animal testing grant 95041 (A. Gaspari). The transgenic mice were produced at the University of Rochester transgenic mouse facility (Cancer Center Core Grant CA11198-5).

\section{References}

1. Gaspari, A. A., and S. I. Katz. 1988. Induction and functional characterization of class II MHC (Ia) antigens on murine keratinocytes. J. Immunol. 140:2956-2963.

2. Gaspari, A. A., M. K. Jenkins, and S. I. Katz. 1988. Class II MHC-bearing keratinocytes induce antigen-specific unresponsiveness in hapten-specific clones. J. Immunol. 141:2216-2220.

3. Bal, V., A. McIndoe, G. Denton, D. Hudson, G. Lombardi, J. Lamb, and R. Lechler. 1990. Antigen presentation by keratinocytes induces tolerance in human T-cells. Eur. J. Immunol. 20:1893-1897.

4. Gaspari, A. A., and S. I. Katz. 1991. Induction of in vivo hyporesponsiveness to contact allergens by hapten-modified $\mathrm{Ia}^{+}$keratinocytes. J. Immunol. 147:4155-4161.

5. Mueller, D. L., M. K. Jenkins, and R. H. Schwartz. 1989. Clonal expansion versus functional clonal inactivation: a costimulatory signalling pathway determines the outcome of T-cell antigen receptor occupancy. Annu. Rev. Immunol. 7:445-480.

6. Young, J. W., L. Koulova, S. A. Soergel, E. A. Clark, R. M. Steinman, and B. Dupont. 1992. The B7/BB-1 antigen provides one of several costimulatory signals for the activation of CD4 ${ }^{+} \mathrm{T}$ lymphocytes by human blood dendritic cells in vitro. J. Clin. Invest. 90:229-237.

7. van-Seventer, G. A., Y. Shimizu, K. J. Hogan, and S. Shaw. 1990. The LFA-1 ligand ICAM-1 provides an important costimulatory signal for T-cell receptor-mediated activation of resting T-cells. J. Immunol. 144:4579-4586.

8. Dustin, M. I., D. Olive, and T. A. Springer. 1989. Correlation of CD2 binding and functional properties of multimeric and monomeric lymphocyte function associated antigen-3. J. Exp. Med. 169:503-517.

9. Armitage, R. J., W. C. Fanslow, L. Strockbine, T. A. Sato, K. N. Clifford, B. M. Macduff, D. M. Anderson, S. D. Gimpel, T. Davis-Smith, C. R. Maliszewski, E. A. Clark, C. A. Smith, K. H. Grabstein, D. Cosman, and M. K. Spriggs. 1992. Molecular and biological characterization of a murine ligand for CD40. Nature (Lond.). 357:80-82.

10. Linsley, P. S., W. Brady, L. Grosmaire, A. Aruffo, N. K. Damle, and J. A. Ledbetter. 1991. Binding of the B cell activation antigen B7 to CD28 costimulates $\mathrm{T}$ cell proliferation and Interleukin-2 accumulation. J. Exp. Med. 173:721-730.

11. Gimmi, C. D., G. J. Freeman, J. G. Gribben, K. Sugita, A. S. Freedman, C. Morimoto, and L. M. Nadler. 1991. B-cell surface antigen B7 provides a costimulatory signal that induces $\mathrm{T}$ cells to proliferate and secrete Interleukin-2. Proc. Natl. Acad. Sci. USA. 88:6575-6579.

12. Liu, Y., Y. Jones, A. Aruffo, K. M. Sullivan, P. S. Linsley, and C. A. Janeway, Jr. 1992. Heat-stable antigen is a costimulatory molecule for CD4 T cell growth. J. Exp. Med. 175:437-445.
13. Lenschow, D. J., G. H.-T. Su, L. A. Zuckerman, N. Nabavi, C. L. Jellis, G. S. Gray, J. Miller, and J. A. Bluestone. 1993. Expression and functional significance of an additional ligand for CTLA-4. Proc. Natl. Acad. Sci. USA. 90:11054-11058.

14. Boussiotis, V. A., G. J. Freeman, J. G. Gribben, J. Daley, G. Gray, and L. M. Nadler. 1993. Activated human B lymphocytes express three CTLA-4 counterreceptors that costimulate T-cell activation. Proc. Natl. Acad. Sci. USA 90:11059-11063.

15. Razi-Wolf, Z., F. Galvin, G. Gray, and H. Reiser. 1993. Evidence for an additional ligand, distinct from B7, for the CTLA-4 receptor. Proc. Natl. Acad. Sci. USA. 90:11182-11186.

16. Thompson, C. B., T. Lindsten, J. A. Ledbetter, S. L. Kunkel, H. A. Young S. G. Emerson, J. M. Leiden, and C. H. June. 1989. CD28 activation pathway regulates the production of multiple T cell-derived lymphokines/cytokines. Proc. Natl. Acad. Sci. USA. 86:1333-1337.

17. June, C. H., J. A. Ledbetter, P. S. Linsley, and C. B. Thompson. 1990. Role of the CD28 receptor in T-cell activation. Immunol. Today. 11:211-216.

17a. Linsley, P. S., E. A. Clark, and J. A. Ledbetter. 1990. The T-cell antigen, CD28, mediates adhesion with $B$ cells by interacting with the activation antigen, B7/BB-1. Proc. Natl. Acad. Sci. USA. 87:5031-5035.

17b. Linsley, P. S., W. Brady, M. Urnes, L. S. Grosmaire, N. K. Damle, and J. A. Ledbetter. 1991. CTLA-4 is a second receptor for the B cell activation antigen B7. J. Exp. Med. 174:561-569.

18. Gaspari, A. A., B. Ferbel, F. Razvi, and R. Polakowska. 1993. Accessory and alloantigen-presenting cell function of A431 keratinocytes that stably express the B7 antigen. Cell. Immunol. 149:291-302.

19. Gaspari, A. A. 1993. Advances in the understanding of contact hypersensitivity. Am. J. Cont. Derm. 4:138-149.

20. Yamamura, M., K. Uyemura, R. Dians, K. Weinberg, T. H. Rea, B. Bloom, and R. L. Modlin. 1991. Defining protective responses to pathogens: cytokine profiles in Leprosy lesions. Science (Wash. DC). 254:277-279.

21. Freeman, G. J., G. S. Gray, C. D. Gimmi, D. B. Lombard, L.-J. Zhou, M. White, J. D. Fingeroth, J. G. Gribben, and L. M. Nadler. 1991. Structure, expression, and T-cell costimulatory activity of the murine homologue of the human B lymphocyte activation antigen B7. J. Exp. Med. 174:625-631.

22. Vassar, R., M. Rosenberg, S. Ross, A. Tyner, and E. Fuchs. 1989. Tissuespecific and differentiation-specific expression of a human K14 keratin gene in transgenic mice. Proc. Natl. Acad. Sci. USA. 86:1563-1567.

23. Gascoigne, J. R. J., Y.-H. Chien, D. M. Becker, J. Kavaler, and M. M. Davis. 1984. Genomic organization and sequence of T-cell receptor $\beta$-chain constant- and joining-region genes. Nature (Lond.). 310:387-391.

24. Nasir A., Z. Chen, B. Ferbel, and A. A. Gaspari. 1993. Preparation of a K14 promoter driven mouse B7 cDNA construct and functional analysis in a transient co-stimulation assay. Clin. Res. 41:606a. (Abstr.)

25. Moroson, H., and M. Furlan. 1970. An improvement in alkaline sucrose density gradient sedimentation of mammalian cell DNA. Radiation Research. 44:713-726.

26. Hogan, B., F. Costantini, and E. Lacy. 1986. Introduction of new genetic information into the developing mouse embryo. In Manipulating the Mouse Embryo. A Laboratory Manual. Cold Spring Harbor Laboratory Press, Cold Spring Harbor, NY. 152-203.

27. Sambrook, J., E. F. Fritsch, and T. Maniatis. 1989. Analysis and cloning of eukaryotic genomic DNA. In Molecular Cloning: A Laboratory Manual, second edition. N. Ford, C. Nolan, and M. Ferguson, editors. Cold Spring Harbor Laboratory Press, Cold Spring Harbor, NY. 9.1-62.

28. Julius, M. H., E. Simpson, and L. A. Herzenberg. 1973. A rapid method for the isolation of functional thymus-derived murine lymphocytes. Eur. J. Immunol. 3:645-649.

29. Breathnach, S. M., S. I. Katz, L. Clement, I. Green, and E. M. Shevach. 1978. Immunologic function of Ia bearing epidermal LC. J. Immunol. 121:2005-2013.

30. Gaspari, A. A., and S. I. Katz. 1991. Contact Hypersensitivity. In Current Protocols in Immunology. J. E. Coligan, A. M. Kruisbeek, D. H. Margulies, E. M. Shevach, and W. Strober, editors. John Wiley \& Sons/New York, NY. Section 4.2:1-5.

31. Streilein, J. W. 1990. Skin associated lymphoid tissues (SALT): the next generation. In The Skin Immune System (SIS). J. D. Bos, editor. CRC press/Boca Raton, Florida. 25-48.

32. Shahinian, A., K. Pfeffer, K. P. Lee, T. M. Kundig, K. Kishihara, A. Wakeham, K. Kawai, P. S. Ohashi, C. B. Thompson, and T. W. Mak. 1993 Differential $\mathrm{T}$ cell costimulatory requirements in CD28-deficient mice. Science (Wash. DC). 261:609-612.

33. Norton, S. D., L. Zuckerman, K. B. Urdahl, R. Shefner, J. Miller, and M. K Jenkins. 1992. The CD28 ligand, B7, enhances IL-2 production by providing costimulatory signal to T cells. J. Immunol. 149:1556-1561.

34. Azuma, M., M. Cayabyab, D. Buck, J. H. Phillips, and L. L. Lanier. 1992. CD28 Interaction with B7 costimulates primary allogeneic proliferative responses and cytotoxicity mediated by small, resting T lymphocytes. J. Exp. Med. 175:353-360.

35. Basham, T. Y., B. H. Nickoloff, T. C. Merigan, and V. B. Morhenn. 1984. Recombinant gamma interferon induces HLA-DR expression on cultured human keratinocytes. J. Invest. Dermatol. 83:88-90. 